\title{
Rigid spine syndrome with respiratory failure
}

\author{
Hiroshi Morita, Kiyohiko Kondo, Kazuo Hoshino, Keiko Maruyama, Nobuo Yanagisawa
}

\begin{abstract}
The pathogenesis and therapy of respiratory failure in the rigid spine syndrome are discussed in two cases who improved with respiratory assistance. In both cases, the partial pressures of oxygen and carbon dioxide were reversed in arterial blood gas analysis and \%VC was less than $30 \%$. Remission from respiratory failure has been obtained by the use of a ventilator during the night. The cause of the respiratory failure in both cases was severe restrictive respiratory dysfunction due to extreme flattening of the chest and fixation of the thorax during respiration as a result of contracture of costovertebral joints. All the previously reported cases of the rigid spine syndrome with respiratory failure died. Appropriate use of the ventilator can improve the prognosis.
\end{abstract}

Since Dubowitz first reported the rigid spine syndrome in $1965,{ }^{1}$ several cases have been reported who fell rapidly into respiratory failure and died. ${ }^{348-11}$ We have experienced two cases of the syndrome with respiratory failure. Both of them have been treated at night with ventilatory assistance from the onset of respiratory failure, for six and two years respectively. The cause of death in fatal cases and beneficial effects of respiratory assistance in this intractable syndrome will be discussed.

\section{Case reports}

Case 1 is an 18 year old female (Fig 1 a,b). Her paternal grandparents were first cousins. Her older sister had a similar stature and died of respiratory failure at the age of 13 . When she was eight years old she experienced exertional dyspnoea, and from the age of 10 had repeated episodes of pneumonia. She was found to have scoliosis at this time. She was first seen at our neurological clinic when she was 11 years old.

On physical examination, she was thin (body height $131 \mathrm{~cm}$, body weight $34 \mathrm{~kg}$ ) and had extreme flattening of the chest. The muscles of the neck, shoulder and paravertebral region were slightly atrophied and weak. There was scoliosis, contractures of elbow joints and bilateral pes equinus. Flexion of the cervical and upper part of the thoracic spine was severely limited. Deep tendon reflexes were absent in the upper extremities and diminished in the lower extremities.

Respiratory function testing showed severe restrictive dysfunction (vital capacity $630 \mathrm{ml}$,
$\%$ VC $30 \%, \mathrm{FEV}_{1 \cdot 0}, 90 \%$ ). Echocardiography showed dilatation of the right ventricle suggesting continuous overload on the right heart due to chronic hypoxia. The electromyogram of the extremities showed moderate myogenic change. Biopsy of the left quadriceps muscle showed variation in the size of fibres with scattered atrophic fibres. Many were in the range of $60-80$ micrometres in diameter. There was slight proliferation of perimysial and endomysial connective tissue. No mitochondrial abnormalities or ragged-red fibres were observed.

When she was 12 years old she was admitted to our hospital with severe dyspnoea. There was cyanosis and orthopnoea and reversal of the partial pressures of oxygen and carbon dioxide $\left(\mathrm{PO}_{2} 35 \mathrm{~mm} \mathrm{Hg} \mathrm{PCO}_{2} \quad 70\right.$ $\mathrm{mm} \mathrm{Hg}$ ). She was diagnosed as having heart failure due to hypoxia. Tracheotomy was performed and respiratory support using a volume cycling ventilator was started in June 1983. There was a remission after two months and she was discharged. Respiratory support using the ventilator only during the night was continued at home. Harrington's instrumentation surgery was carried out for the scoliosis in 1984.

In 1987 circulatory and respiratory functions were re-examined. Body growth had continued (body height $151 \mathrm{~cm}$, body weight $39 \mathrm{~kg}$ ). The echocardiogram was normal, and respiratory function had not deteriorated (vital capacity $890 \mathrm{ml}, \% \mathrm{VC} 30 \%, \mathrm{FEV}_{1.0^{\circ}}$ 。 $99 \%$ ). On chest radiograph, the diaphragm moved normally but thoracic movement was severely limited during respiration with little movement of the costae and the costovertebral joints. There was no atrophy of intercostal muscles on CT scan. Since 1982 there has been no evidence of progression of the limitation of range of neck flexion, contractures of the elbow joints, pes equinus and muscular weakness. She is now able to live a fairly normal life.

Case 2 is a 37 year old male (fig $1 \mathrm{c}$, d). The patient's parents were first cousins. He has a brother and a sister, who are healthy with normal stature. His son and daughter are also healthy.

When he was five years old his parents found that he was not able to flex his neck. He was poor at sports. He later worked as an accountant leading a normal life until the age of 35 years. In January 1987 he noticed dyspnoea and palpitation on exertion. The dyspnoea gradually progressed, and his family noticed that he was drowsy during the daytime. On 22 May 1987 he was admitted to our hospital.

His height was $161 \mathrm{~cm}$, and his weight $39 \mathrm{~kg}$. 


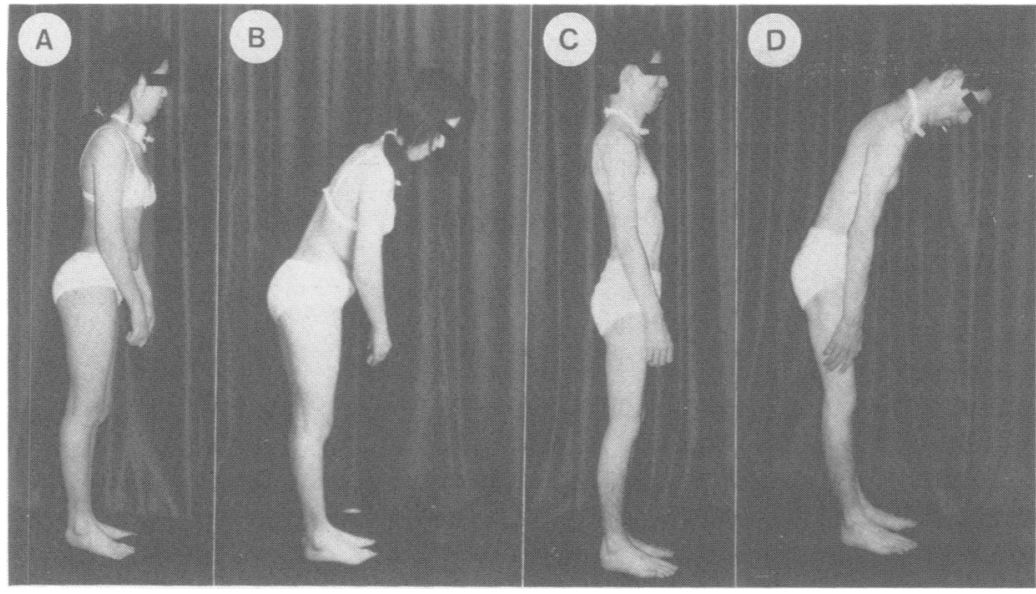

Figure 1 Photographs of patients. (a), (b) case 1 at 16 years old. (c), (d) case 2 at 35 years old. Both patients show marked limitation of flexion of the cervical and upper part of the thoracic spine and flattening of the chest.

He showed cyanosis. The thorax was thin, and there was gynaecomastia. Analysis of arterial blood gas showed hypoxia and compensatory respiratory acidosis $\left(\mathrm{pH} 7 \cdot 340, \mathrm{PCO}_{2} 71.9\right.$ $\mathrm{mm} \mathrm{Hg}, \mathrm{PO}_{2} 38.0 \mathrm{~mm} \mathrm{Hg}, \mathrm{HCO}_{3} 38.0 \mathrm{mM} / 1$, BE $9.3 \mathrm{mM} / 1$ ). Respiratory function testing showed severe restrictive dysfunction (vital capacity $1210 \mathrm{ml} \% \mathrm{VC} 32 \%, \mathrm{FEV}_{1 \cdot 0^{\circ}} 100 \%$ ). The electrocardiogram showed complete rightbundle-branch block and right ventricular hypertrophy, while the echocardiogram showed right ventricular hypertrophy and dilatation of the pulmonary artery, all of which suggested continued pulmonary hypertension. $\mathrm{He}$ was diagnosed as having pulmonary hypertension and heart failure due to chronic hypoxia.

On neurological examination, he was slightly drowsy but had normal intelligence. The muscles of the neck, proximal part of the upper extremities, and the paravertebral regions were slightly atrophied and weak. There was severe limitation of flexion of the cervical spine and extension of the bilateral foot joints. Deep tendon reflexes were absent in the four extremities. There was no abnormality in coordination, sensation or gait.

Electromyogram of the extremities and paravertebral regions showed polyphasic potentials of 0.3 to $0.5 \mathrm{mV}$ in amplitude, but no typical myogenic pattern. Muscle biopsy of the left biceps brachii showed small fibres scattered throughout the specimen. No mitochondrial abnormalities or ragged-red fibres were observed. ATPase reaction at $\mathrm{pH} \mathbf{9 . 4}$ showed type II fibre predominance. There was no proliferation of the connective tissue or structural change within the muscle fibres. Computerised tomography (CT) showed atrophy of the paravertebral muscles especially at the cervical and upper thoracic levels, with the exception of the intercostal muscles.

Tracheotomy was performed and respiratory support with a ventilator was started. One month later pulmonary hypertension had decreased to normal. Withdrawal from the ventilator was tried, but he required respiratory support for at least eight hours a day because of the reversal of $\mathrm{PO}_{2}$ and $\mathrm{PCO}_{2}$ in the arterial blood. After four months of assisted ventilation he was discharged from hospital with a portable ventilator for nocturnal ventilation at home. Re-examination of circulatory and respiratory functions was performed one year later. The echocardiogram was normal, but respiratory function was unchanged. The diaphragm moved normally without paradoxical abdominal movement but thoracic movement was not seen on the chest radiograph (fig 2). Since then he has been able to work normally and enjoy sports with his family.

\section{Discussion}

The major symptoms of the rigid spine syndrome are limitation of flexion of the cervical and dorsolumbar spine without severe muscular weakness. ${ }^{2-4}$ Although the syndrome is considered to have a good prognosis, some patients died of respiratory failure in the first or second decade (table 1$)^{348-11}$. Such patients had severe restrictive ventilatory failure except for one case with fetal cardiomyopathy reported by Colver et al. ${ }^{8}$

In our two cases respiratory failure was the major symptom. In both cases it was due to
Figure 2 Chest radiograph of case 2 . (a) inspiratory phase, $(b)$ expiratory phase; thorax is fixed during respiration.
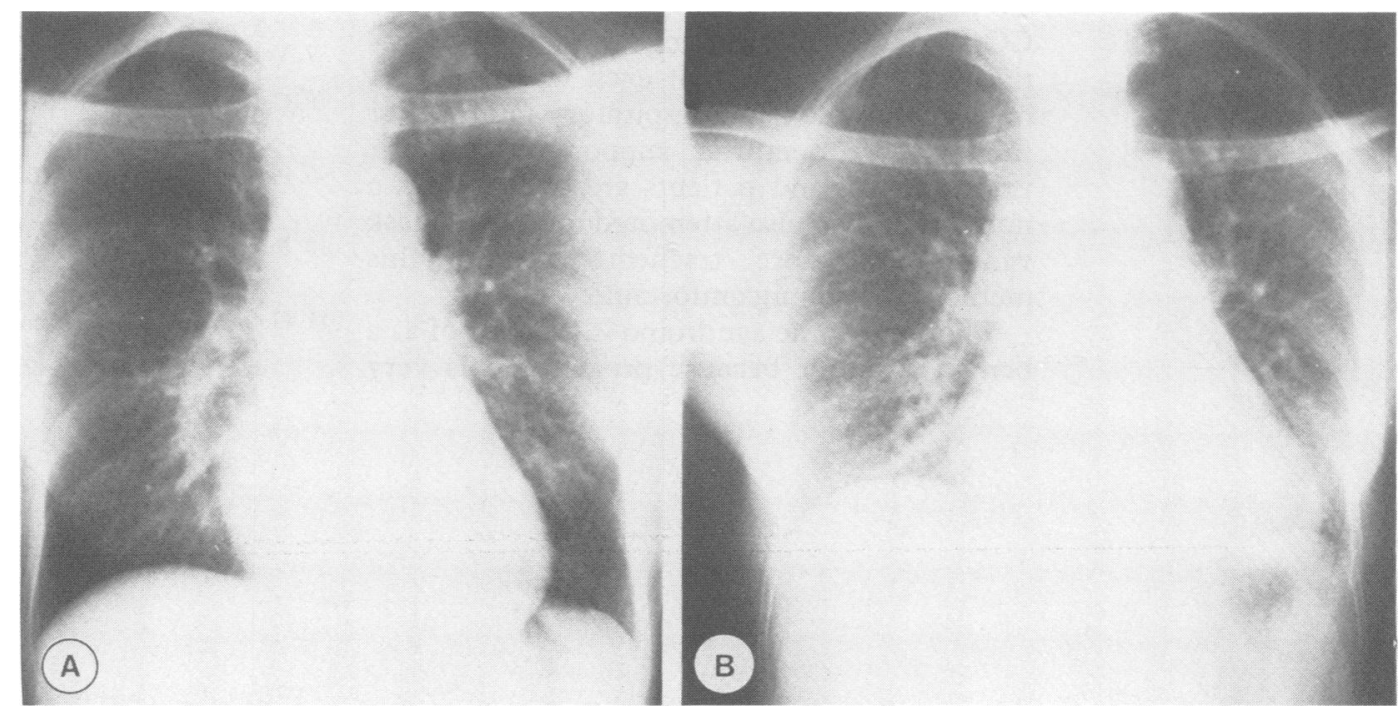
Table Rigid spine syndrome with respiratory dysfunction

\begin{tabular}{|c|c|c|c|c|c|c|c|c|}
\hline Cases & Age & Sex & $\begin{array}{l}\text { Respiratory } \\
\text { function }\end{array}$ & $E C G$ & Cause of death & $C K$ & Muscle biopsy & Other findings \\
\hline $\begin{array}{l}\text { van Munster } \\
(1986)\end{array}$ & 20 & $M$ & $\begin{array}{l}\text { Cyanosis from } \\
19 \text { yrs restrictive }\end{array}$ & RAD & $\begin{array}{l}\text { Acute right } \\
\text { heart failure }\end{array}$ & $3 \times \mathrm{NUL}$ & $\begin{array}{l}\text { Variation of fibre size } \\
\text { Increase of connective tissue } \\
\text { (elector trunci m) }\end{array}$ & $\begin{array}{l}\text { Contracture of hip and } \\
\text { knee joints }\end{array}$ \\
\hline \multirow[t]{2}{*}{ Poeve (1985) } & 13 & $\mathbf{F}$ & Restrictive & RVH & $\begin{array}{l}\text { Acute right } \\
\text { heart failure }\end{array}$ & Normal & $\begin{array}{l}\text { Mild variation of fibre size } \\
\text { (deltoid } \mathbf{m})\end{array}$ & Scoliosis \\
\hline & 21 & $\mathbf{M}$ & Restrictive & $\begin{array}{l}\text { RBBB } \\
\text { RVH }\end{array}$ & $\begin{array}{l}\text { Acute right } \\
\text { heart failure }\end{array}$ & $2 \times \mathrm{NUL}$ & $\begin{array}{l}\text { Variation of fibre size } \\
\text { Increase of connective tissue } \\
\text { type II predominance } \\
\text { (biceps br } \mathrm{m} \text { ) }\end{array}$ & $\begin{array}{l}\text { Scoliosis, equinus } \\
\text { Contracture of elbow } \\
\text { joints }\end{array}$ \\
\hline Pavone (1983) & 10 & $\mathbf{M}$ & $\begin{array}{l}\text { Weakness of } \\
\text { intercostal muscle }\end{array}$ & Normal & $\begin{array}{l}\text { Cardiopulmonary } \\
\text { insufficiency }\end{array}$ & Normal & $\begin{array}{l}\text { Increase of connective tissue } \\
\text { (elector trunci } \mathrm{m} \text { ) }\end{array}$ & $\begin{array}{l}\text { Limited extension of } \\
\text { elbow and knee } \\
\text { joints }\end{array}$ \\
\hline Fukui (1983) & 15 & $M$ & ${ }_{0}^{\circ} \mathrm{VC} 30^{\circ}{ }_{\mathrm{o}}$ & Sinus & Sudden death & $3 \times \mathrm{NUL}$ & Variation of fibre size & Scoliosis, equinus \\
\hline Goto (1986) & & & $\begin{array}{l}\mathrm{PO}_{2} 48 \mathrm{~mm} \mathrm{Hg} \\
\mathrm{PCO}_{2} 75 \mathrm{~mm} \mathrm{Hg}\end{array}$ & Tachycardia & & & $\begin{array}{l}\text { Increase of central nuclei } \\
\text { Increase of connective tissue } \\
\text { (deltoid } \mathrm{m} \text { ) }\end{array}$ & High arched palate \\
\hline Case 1 & 18 & $\mathrm{~F}$ & $\begin{array}{l}\circ \mathrm{VCC} 30^{\circ} \\
\mathrm{PO}_{2} 35 \mathrm{~mm} \mathrm{Hg} \\
\mathrm{PCO}_{2} 72 \mathrm{~mm} \mathrm{Hg}\end{array}$ & Normal & & Normal & $\begin{array}{l}\text { Mild variation of fibre size } \\
\text { Mild increase of connective } \\
\text { tissue } \\
\text { (quadriceps } \mathrm{m} \text { ) }\end{array}$ & $\begin{array}{l}\text { Scoliosis } \\
\text { equinus } \\
\text { Contacture of elbow } \\
\text { joints }\end{array}$ \\
\hline Case 2 & 37 & $\mathbf{M}$ & $\begin{array}{l}{ }_{0}^{\circ} \mathrm{VC} 32 \%^{\circ} \\
\mathrm{PO}_{2} 38 \mathrm{~mm} \mathrm{Hg} \\
\mathrm{PCO}_{2} 72 \mathrm{~mm} \mathrm{Hg}\end{array}$ & $\begin{array}{l}\text { CRBBB } \\
\text { RVH }\end{array}$ & & Normal & $\begin{array}{l}\text { Mild variation of fibre size } \\
\text { type II predominance } \\
\text { (biceps brachii m) }\end{array}$ & $\begin{array}{l}\text { Limited extension of } \\
\text { foot joints } \\
\text { Gynecomastia }\end{array}$ \\
\hline
\end{tabular}

$\mathrm{CK}=$ creatine kinase, $\mathrm{RAD}=$ right axis deviation, $\mathrm{RVH}=$ right ventricular hypertrophy, $(\mathrm{C}) \mathrm{RBBB}=($ complete-) right-bundle-branch-block, $\mathrm{NUL}=$ normal upper limit.

restrictive ventilatory dysfunction. Because non-invasive investigation of the heart showed no cardiac impairment except for an apparent secondary change due to respiratory failure, it was unlikely that cardiac dysfunction was the cause of this respiratory failure.

Atrophy and weakness of the respiratory muscles were not important factors in the respiratory failure, but the thin and fixed thorax were important. The intercostal space was kept wide and fixed during respiratory movement (fig 2), and there was no atrophy of the intercostal muscles or the diaphragm. These findings suggest that contracture of the costovertebral joints caused the fixation of the thorax. It may be suspected that the previous reported cases also had contracture of costovertebral joints and that this was one of the causes of the respiratory dysfunction.

This is the first report of patients with the rigid spine syndrome with respiratory failure using a ventilator. Continuous support of respiration was not necessary except when the respiratory failure deteriorated because of infection. But when support was stopped inversion of $\mathrm{PO}_{2}$ and $\mathrm{PCO}_{2}$ gradually occurred. To protect patients from respiratory failure or $\mathrm{CO}_{2}$ narcosis, intermittent support of respiration must be carried out even when patients have no symptoms of respiratory failure. For this purpose nocturnal support is good for practical use, and patients are able to lead a normal life. We also attempted to use the mask ventilation before tracheotomy, but this method was too uncomfortable.

The rigid spine syndrome is thought of as a benign disorder because progression is very slow and atrophy is limited in its distribution. In our two cases no progression of muscular weakness or contracture of joints appeared after using a ventilator for five years in case 1 and two years in case 2 . The nocturnal ventilation is a good method for protecting the patient from respiratory failure, and improving the quality of life.

We are grateful to Dr Goto and Dr Ohyama, Saku Central Hospital, for their co-operation in the treatment of the cases.

1 Dubowitz V. Pseudo-muscular dystrophy. In: Research in Muscular Dystrophy. Proc Third Symposium, Research Committee of the Muscular Dystrophy Group of Great Britain. London, Pitman Medical, 1965:57-73.

2 Dubowitz V. Rigid spine syndrome. In: Muscle biopsy: a practical approach 2nd ed. East Sussex: Baillière Tindall 1985:617-20.

3 Poewe W, Willeit $H$, Sluga E, Mayr U. The rigid spine syndrome. A myopathy of uncertain nosological position. J Neurol Neurosurg Psychiatry 1985;48:887-93.

4 van Munster ETL, Joosten EMG, van MunsterUijtdehaage MAM, Kruls HJA, Laak HJ. The rigid spine syndrome. J Neurol Neurosurg Psychiatry 1986;49: syndrome.

5 Seay AR, Ziter FA, Petajan JH. Rigid spine syndrome. A type I fibre myopathy. Arch Neurol 1977;34:119-22.

6 Mussini JM, Gray F, Hauw JJ, Piette AM, Prost A. Rigid spine syndrome. Histological examinations of male and female cases. Acta Neuropathol (Berl) 1981;suppl 7: 331-3.

7 Vogel P, Goegel HH, Seitz D. Rigid spine syndrome in a girl. J Neurol 1982;228:259-65.

8 Colver AF, Steer CR, Godman MJ, Uttley WS. Rigid spine syndrome and fatal cardiomyopathy. Arch Dis Child 1981;56:148-51.

9 Pavone L, Gullotta F, La Rosa M, Grasso A. Rigid spine syndrome. Some evidence of varying pathological syndrome. Some evidence of varying

10 Fukui R, Ishimoto S, Tabira T, Goto I, Kuroiwa Y. A case of rigid spine syndrome associated with cytoplasmic bodies rigid spine syndrome associated with cytoplasmic
and rod like particles. Clin Neurol 1983;32:531-8.

11 Goto I, Ishimoto S, Yamada T, Hara H, Kuroiwa Y. The rigid spine syndrome and Emery-Dreifuss muscular dystrophy. Clin Neurol Neurosurg 1986;88:293-8. 